\title{
COMPLEX ISSUES OF REGIONAL GROWTH DEPENDENCE ON THE LEVEL OF FINANCIAL SECTOR DEVELOPMENT
}

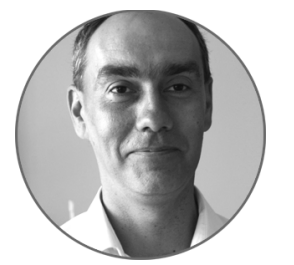

Konstantin V. KRINICHANSKII

South Ural State University (National Research University), Chelyabinsk, Russian Federation

kkrin@ya.ru

Corresponding author

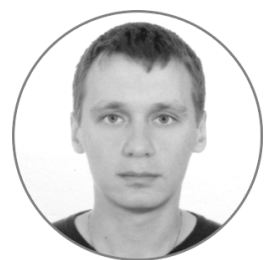

\section{Andrei V. FAT'KIN}

South Ural State University (National Research University), Chelyabinsk, Russian Federation andfatkin@yandex.ru

\section{Article history:}

Received 2 December 2016

Received in revised form

26 December 2016

Accepted 12 January 2017

Translated 25 August 2017

Available online 15 September 2017

JEL classification: $\mathrm{G} 18, \mathrm{G} 21,010,018$, 043

Keywords: emerging market, financial system, economic development, regression mode

\begin{abstract}
Importance The paper develops the area of endogenous economic growth theory that focuses on the relationships between financial development and economic dynamics at the national and sub-national levels.

Objectives The study aims to identify regular differences in the level and statistical significance of the coefficients of regression models with financial development variables for groups of regions with different levels of financial sector development averaged for the studied period.

Methods To estimate coefficients, we use an individual fixed-effect model. Regions are classified in terms of the composite index of density of banking services in the region. We use real GRP per capita as an indicator of economic dynamics. The analysis covers the panel data on 75 Russian regions for the period of 2002-2014.

Results We found that the impact of financial development indices on economic growth is more intensive in groups of regions with a moderate level of financial development.

Conclusions and Relevance The findings support the hypothesis on nonmonotonic dependence of finance and growth among different groups of Russian regions.
\end{abstract}

(c) Publishing house FINANCE and CREDIT, 2016

The editor-in-charge of this article was Irina M. Komarova

Authorized translation by Andrey V. Bazhanov

Discussions on the driving forces of the growth of regional economies in Russia have recently been much more in the area of discussion of the causes and

${ }^{\dagger}$ For the source article, please refer to: Криничанский К.В., Фатькин A.В. Сложные вопросы зависимости регионального роста от уровня развития финансового сектора. Региональная экономика: теория и практика. 2017. Т. 15. Вып. 6. С. 1068-1081.

URL: https://doi.org/10.24891/re.15.6.1068 impediments to growth in Russian regions, at the expense of a deep and thorough examination of the sources of regional growth.

The need for such a study stems from the urgent imperative to create a technology-driven model for the domestic economy's growth and appropriate structural reforms. 
There are very few such extensive empirical studies in Russia, despite the fact that many of these reforms, from small business to innovation, from labor market to the financial sphere, have been thoroughly analyzed in foreign scholarly works, including an assessment of the impact of potential impulses on economic outcomes, including the regional level ${ }^{1}$ [1-4].

The role of financial systems and financial markets in regional development in the Russian Federation is one of the neglected issues of this agenda.

At present, the vast reservoir of academic works, which are in line with the oft-quoted works by J. Schumpeter [4], J. Hicks [5], R. Goldsmith [6], R. McKinnon [7], significantly increased in the 1990-2000s thanks to the contributions by R. King, R. Levine, T. Beck, N. Loayza [8-11] and other scholars, promotes the view that the financial development of countries has a significant positive direct effect on their economic growth.

The inquiries made a little later about the impact of the development of financial systems on the economic trends at the in-country level (L. Guiso and others [12], X. Cheng, H. Degryse [13], J. Kendall [14], J. Zhang and others [15]), generally confirm the results of the intercountry analysis.

However, the authors are not completely unanimous in the assessment and interpretation of explained phenomena and the relationships that have been discovered. Serious disputes have been caused by the ambiguity of the conclusion as to the direction of the causal nexus between finance and growth.

The scholars suggest different approaches when explaining the mechanisms of transition from finance to growth.

Finally, some works, like by P. Demetriades, K. Hussien [16], F. Rioja and N. Valev [17], M.O. Odedokun [18], contain certain evidence that the consideration of economic growth through the development of the financial systems of countries or regions within them requires to precise the composition of the samples to be analyzed, as well as the time intervals. This may imply the sensitivity of the growth

\footnotetext{
${ }^{1}$ Organization for Economic Cooperation and Development (OECD). Regions at a Glance. Paris, OECD Publishing, 2016, 181 p.
}

variable response to the financial variables, to the conditions that could be described as the stages of development of bodies of interest (countries, regions), or to the economic cycle.

Within the framework of this article, we are particularly interested in the approaches and results obtained by some researchers (R. Levine et al. [19], J. De Gregorio and P. Guidotti [20], F. Rioja and N. Valev [21]) in the works that determined how economic growth is sensitive to the different levels of financial development of countries.

The impact of the development of banking mediation in the regions of Russia on the trends of growth of the Russian Federation (RF) subjects has been considered by K. Krinichanskii ${ }^{2}$ [22]. His works, in particular, show that the growth performance of the Russian regions is closely and positively correlated with the financial development indicators of the RF subjects.

Differences in the development levels of the regions' financial systems have an impact on the dispersion of economic development. So the regions with more advanced market financial systems may have an advantage, and the regions with the less developed ones experience growth constraints.

This study aims to identify the non-monotonicity of regression dependence of finance and economic growth at the regional level, that is the dependence of model parameters that explain the relationship between bank mediation and per capita gross regional product, on the relative levels of such mediation in the regions of Russia.

The open data of Rosstat and Bank of Russia form an information base for the study.

The collected data panel contains annual 2002-2014 index numbers of gross regional product per capita (including inflation-adjusted), deposits, credits, and

\footnotetext{
${ }^{2}$ See the author's other articles: Krinichanskii K.V. [Financial Markets: An Analysis of the Impact on the Socio-Economic Processes in the Russian Regions]. Regional'naya ekonomika: teoriya i praktika = Regional Economics: Theory and Practice, 2015, vol. 13, iss. 4, pp. 13-27. (In Russ.); Krinichanskii K.V., Fat'kin A.V. [Financial Systems of the Russian Regions: An Analysis of Post-Crisis Development Trends]. Regional'naya ekonomika: teoriya i praktika = Regional Economics: Theory and Practice, 2016, vol. 14, iss. 10, pp. 75-91. (In Russ.)
} 
number of structural units of credit organizations. The data panel covers 75 regions of Russia ${ }^{3}$.

In our analysis, we used a fixed-effect model of the following specification:

$$
\begin{aligned}
& Y_{i t}=\beta \cdot \dot{X}_{i t}+\gamma_{0} \bullet F D_{i t} \bullet L R_{i t}+\gamma_{1} F D_{i t} \bullet M R_{i t}+ \\
& +\gamma_{2} F D_{i t} \bullet H R_{i t}+\alpha_{i}+\varepsilon_{i t}, \\
& i=1, \ldots, N ; t=1, \ldots, T ; \\
& \varepsilon_{i t} \sim i . i . d . N\left(0, \sigma^{2}\right) ; \\
& E\left(X_{i t}, \varepsilon_{j s}\right)=0 \forall i, j,=1, \ldots, N, t, s=1, \ldots, T,
\end{aligned}
$$

where $Y_{i t}$ is the logarithm of real gross regional product per capita;

$$
\dot{X}_{i t} \quad \text { is the row vector of control variable values; }
$$

$\beta$ is the coefficient column vector in control variables;

$F D_{i t}$ is the variable that characterizes the development of the financial system of the region;

$\gamma_{j}$ is the coefficient for financial development variable under test;

$L R_{i t}, \quad M R_{i t}$ and $H R_{i t}$ are the dummy variables characterizing the inclusion of the region in the group with lower, moderate and higher financial development, respectively;

$\alpha_{i}$ is the unobservable time-invariant (fixed) effect that characterizes the individual characteristics of a particular region;

$\varepsilon_{i t}$ is the random error vector;

$i, t$ are the indexes indicating the region (the Russian Federation subject) and the year, respectively.

Estimates of the parameters of this model are based on the assumptions of independent and equally distributed residuals and exogeneity of explanatory variables.

We consider ratios Loans to Gross Regional Product 4 Deposits to Gross Regional Product ${ }^{5}$, and the logarithm of the number of internal structural units of credit

\footnotetext{
${ }^{3}$ For reasons of incomplete information or outlying observation, the following regions were excluded from the initial set of data containing observations of 80 constituents of the Russian Federation: the Republic of Ingushetia, Chechen Republic, Sakhalin Oblast, Jewish Autonomous Oblast, and the Chukotka Autonomous Okrug.
}

organizations and their affiliates per 10,000 persons, as the explanatory variables characterizing the development of the financial system of the region.

Thus, the proposed model specification allows the totality of the regions to be divided into three groups in terms of the level of development of their financial systems and assess the coefficients of financial development variables for these three categories of regions.

Since the boundary between the groups that might reflect the non-linearity of the finance and growth dependence is not known in advance, we apply the approach of sliding threshold values of grouping indicator. As the indicator, a composite index of banking services density (hereinafter CBSDI index) in the region averaged for the studied period ${ }^{6}$ has been selected in this study. To calculate the sliding threshold values, we set different critical levels of the percentiles:

- 20th, 30th, and 40th percentiles to determine the lower threshold value of the classifying indicator;

- 60th, 70th, and 80th percentiles to determine the higher threshold value of the classifying indicator.

The experimental thresholds obtained are presented in Fig. 1 and the groupings of regions of the Russian Federation calculated on their basis, are shown in Tables 1, 2, and 3.

The bounds shown in Fig. 1 allow us to enter dummy variables that determine each region's membership of a financial development group according to the combinations of percentile ranks, starting with a combination of the 20th percentile rank and the 60th one, and up to the combination of the 40th percentile rank and the 80th one.

Now, let us draw attention to the work by F. Rioja and N. Valev [21], where the authors argue that the growth

\footnotetext{
${ }^{4}$ Credits and other invested assets allotted to individual residents and resident legal entities in Russian rubles and foreign currency

${ }^{5}$ Deposits of legal entities and individuals in Russian rubles and foreign currency.

${ }^{6}$ To calculate this index, we use the Bank of Russia's methodology presented in the annual Banking Supervision Report. URL: http://www.cbr.ru/publ/?Prtld=nadzor. We determine a revised CBSDI index, which is calculated according to a common methodology for all years of observation.
} 
in countries with moderate development of financial systems is more sensitive to financial variables.

Using these arguments as the basis to formulate our own hypothesis, we assume that the performance of banking systems in regions with a moderate indicator of banking services density will also have higher and more significant factor estimates in growth regressions.

This means the possibility to find the lower and upper threshold values of the variable that is "responsible" for financial development.

Regions with a relatively higher level of financial development, reaching which the financial situation ceases to have an equally intense impact on economic growth, as in the case of regions with a moderate level of financial development, shall have the value of a classifying variable above the upper threshold.

Regions with a relatively weak financial sector and transmission mechanism from finance to growth (when, on average, an increase in the extent of the financial sector does not have a significant impact on growth) shall have the CBSDI variable value below the lower threshold.

Regions with a moderate level of financial sector development shall have the CBSDI variable value between the lower and upper thresholds.

Then in our study, we use a financial variable "responsible" for classifying the regions instead of using a few ones, as it is done in the work by F. Rioja and N. Valev [21], where the regression models assess the coefficients using the same financial variable as the classifying one.

As we have already said, in order to determine the thresholds for the financial development of Russian regions, we take pairs drawn from each lower and upper percentile ranks. These pairs are specified by the row and column intersection in Table 4. This table shows the values for estimating coefficients of the Loans to Gross Regional Product variable in regressions for regional growth. As it is shown, the coefficients are positive and relevant at 1- or 5-percent levels for all the objects under observation.

Now, let us compare the values in the table cells for the different financial-development-level region groups.
Note that the test condition of non-monotonicity is the higher sensitivity of the variable being tested in regression with the moderate banking mediation development regions.

We may notice that this condition is met in five of the nine group regression options.

For instance, the coefficient of Loans to Gross Regional Product variable in the regression model built for the group of moderate financial-development-level regions in the 20/70th percentile classification is equal to 0.31 . This is more than a similar coefficient for the group of regions with relatively lower financial sector development (0.259) and for regions with relatively higher development (0.276).

We can say about the regularity of the tested condition, starting with the threshold of the 20/60th percentile and up to the 30/80th percentile threshold.

This means that the behavior of the Loans to Gross Regional Product variable does not negate the hypothesis of the existence of a non-linearity of the measured relationships between finance and growth.

In our case, it is found that the lower threshold of the level of financial development of regions is around the 20th percentile (the composite index of banking services density is less than 0.739), and the upper one is around the 80th percentile (the composite index of banking services density is above 0.986).

Let us explore the relationship we are assessing, using another variable of financial development, namely, the Deposits to Gross Regional Product variable, Table 5.

The results show that the test indicator Deposits to Gross Regional Product, like the previous Loans to Gross Regional Product, is positively associated with regional growth, and the coefficients in this indicator are statistically relevant for all the models summarized in Table 5.

However, it can be noted that the estimated coefficient values are regularly higher in regressions with the lower financial development regions.

For illustrative purposes, we would arbitrarily take the 30/70th percentile classification. For this 
classification, the coefficient in the group of regions with moderate financial development level is 0.884 ; group with lower financial development level, it is 1.119; and in the group with higher financial development level, the coefficient is 0.671 .

Thus, in this case, the hypothesis of non-monotonicity of the dependence of finance and growth at the level of Russian regions is rejected.

Instead, we see a monotonic increase in the values of the estimated coefficients from the group of regions with relatively lower financial development level to the group with relatively higher financial development level.

To explain the result obtained, we can imagine the effect of a decreasing return on savings. That is, with the growth of the region's financial development (including the increase in the savings activity of its residents), additional amounts of generated by the population and enterprises deposits are contributing a relatively smaller amount to growth. This is due to the redistributive effects brought in by the integrated banking system.

Moreover, the fundamental reason for this may be a lack of reliable and highly effective credit financing for investment projects in the regions (indirectly, this may be proved true by a lack of credit in capital investment financing, and the opportunistic behavior of bank managers who finance, or would rather finance, the projects they are more interested in instead of the best ones, in economic terms).

Finally, we consider the third variable under test, that is, we assess the relationship between the growth in the groups of the Russian Federation regions and the number of structural units per population size, Table 6.

As in the previous cases, while checking the non-monotonic condition of the relationship being studied, we pay attention to those table cells where the values of the regression coefficients in the groups of regions with moderate financial development level are higher or not lower, but at a higher level of reliability than in the comparable groups.

Such a result is observed in six of the nine regional group comparison cases.
We can state that the variable "responsible" for the number of structural units per 10,000 people in the groups of regions with moderate banking services density level is more sensitive in growth models than in the two other groups of regions.

Thus, the analysis of the models with two of the three indicators of regional banking systems' development reveals the non-monotonicity of the finance and growth relationships being investigated.

Moreover, in our study, the estimates of the upper threshold value of the classifying variable in the models with the variables under test Loans to Gross Regional Product and Number of Internal Structural Units per 10,000 People coincide, and the lower threshold value estimates differ for the regression data.

Alongside this, considering the intersection of the ranges of percentile ranks corresponding to the condition of non-monotonicity of the dependence analyzed (Tables 4 and 6), it is possible to speak of the lower threshold corresponding to the 30th percentile rank, common to the models with two different test variables.

So, using the values of the classifying variable Adjusted Composite Index of Banking Services Density in Region corresponding to the found lower threshold (30th percentile) and upper threshold (80th percentile), and the minimum and maximum averages of this variable in the regions, we can set the ranges of values for this variable that correspond to the three target groups of regions, i.e. the ones with lower, moderate, and higher financial development in the context of the non-linear relationship between finance and growth.

Thus, such interval-fixed thresholds of the variable Adjusted Composite Index of Banking Services Density in Region, as, respectively, from 0.25 to 0.83 and from 0.94 to 1.74 , meet the lower and higher levels of financial development of the regions, with their corresponding weaker elasticity of growth to financial variables. The moderate level of financial development of the regions, which meets the requirement for more intensive growth under the impact of the financial intermediation factor, is set by the range of composite index of banking services density in region from 0.83 to 0.94 . 
Summarizing the work undertaken, we can note that the results obtained on the basis of the empirical region-level data generally confirm the country-level analysis findings of F. Rioja and N. Valev [21].

The most statistically significant impact of the two indicators (weighted by gross regional product of credit and number of structural units of credit organizations rated on the population base) on economic growth in Russian regions has been reflected in the moderatelevel financial development groups.

This favors the non-monotonicity of the studied relationship of finance and growth at the level of Russian regions.

While we can therefore speak of achieving the objectives of this work, we note that the results should not be considered as final.
As further studies to be undertaken, it would be useful to verify the results on the basis of other classification options, additional test variables "responsible" for financial development, and alternative models for regression analysis of the panel data.

This may include the application of dynamic panel analysis models, which have the best properties in terms of control of endogeneity, than the model with individual fixed-effects applied in this study.

Finally, the issue of how to adjust economic policies in the financial sector, with the knowledge of the nonmonotonic relationships between regional growth and indicators for the bank mediation development in the regions, requires close scrutiny and conceptual development. 
Table 1

Groups of regions with lower financial development, by composite index of banking services density in the region, averaged for 2002-2014

\begin{tabular}{|c|c|c|c|c|}
\hline \multirow{2}{*}{ Region } & \multirow{2}{*}{$\begin{array}{l}\text { Financial } \\
\text { Development } \\
\text { Indicator value }\end{array}$} & \multicolumn{3}{|c|}{$\begin{array}{l}\text { Upper and lower percentile ranks, and the criteria that determine } \\
\text { the threshold values }\end{array}$} \\
\hline & & $\begin{array}{l}20 / 60,20 / 70,20 / 80 \\
C B S D I<0.739\end{array}$ & $\begin{array}{l}30 / 60,30 / 70,30 / 80 \\
C B S D I<0.774\end{array}$ & $\begin{array}{l}40 / 60,40 / 70,40 / 80 \\
C B S D I<0.825\end{array}$ \\
\hline Amur Oblast & 0.812 & - & - & + \\
\hline Kemerovo Oblast & 0.801 & - & - & + \\
\hline Pskov Oblast & 0.8 & - & - & + \\
\hline Mari El Republic & 0.794 & - & - & + \\
\hline Lipetsk Oblast & 0.79 & - & - & + \\
\hline Penza Oblast & 0.782 & - & - & + \\
\hline Republic of Buryatia & 0.775 & - & - & + \\
\hline Krasnoyarsk Krai & 0.774 & - & + & + \\
\hline Sakha (Yakutia) Republic & 0.762 & - & + & + \\
\hline Leningrad Oblast & 0.762 & - & + & + \\
\hline Volgograd Oblast & 0.758 & - & + & + \\
\hline Arkhangelsk Oblast & 0.756 & - & + & + \\
\hline Tver Oblast & 0.745 & - & + & + \\
\hline Orenburg Oblast & 0.741 & - & + & + \\
\hline Tambov Oblast & 0.74 & - & + & + \\
\hline Astrakhan Oblast & 0.736 & + & + & + \\
\hline Republic of Bashkortostan & 0.728 & + & + & + \\
\hline Republic of Adygea & 0.723 & + & + & + \\
\hline Republic of Khakassia & 0.72 & + & + & + \\
\hline Republic of Kalmykia & 0.709 & + & + & + \\
\hline Komi Republic & 0.701 & + & + & + \\
\hline Tyumen Oblast & 0.695 & + & + & + \\
\hline Bryansk Oblast & 0.682 & + & + & + \\
\hline Zabaykalsky Krai & 0.657 & + & + & + \\
\hline Kurgan Oblast & 0.648 & + & + & + \\
\hline Karachay-Cherkess Republic & 0.622 & + & + & + \\
\hline Republic of North Ossetia-Alania & 0.621 & + & + & + \\
\hline Kabardino-Balkar Republic & 0.559 & + & + & + \\
\hline Tyva Republic & 0.502 & + & + & + \\
\hline Republic of Dagestan & 0.249 & + & + & + \\
\hline
\end{tabular}

Note. The region included in the group is marked with "+", the not included one is marked with "-".

Source:Authoring 
Table 2

Groups of regions with moderate financial development, by composite index of banking services density in the region, averaged for 2002-2014

\begin{tabular}{|c|c|c|c|c|c|c|c|c|c|c|}
\hline \multirow{2}{*}{ Region } & \multirow{2}{*}{$\begin{array}{l}\text { Financial Development } \\
\text { Indicator value }\end{array}$} & \multicolumn{9}{|c|}{ Upper and lower percentile ranks } \\
\hline & & $20 / 60$ & $20 / 70$ & $20 / 80$ & $30 / 60$ & $30 / 70$ & $30 / 80$ & $40 / 60$ & $40 / 70$ & $40 / 80$ \\
\hline Moscow Oblast & 0.985 & - & - & + & - & - & + & - & - & + \\
\hline Voronezh Oblast & 0.977 & - & - & + & - & - & + & - & - & + \\
\hline Kaluga Oblast & 0.975 & - & - & + & - & - & + & - & - & + \\
\hline Republic of Tatarstan & 0.965 & - & - & + & - & - & + & - & - & + \\
\hline Tula Oblast & 0.959 & - & - & + & - & - & + & - & - & + \\
\hline Republic of Mordovia & 0.957 & - & - & + & - & - & + & - & - & + \\
\hline Khabarovsk Krai & 0.947 & - & - & + & - & - & + & - & - & + \\
\hline Ivanovo Oblast & 0.945 & - & - & + & - & - & + & - & - & + \\
\hline Chelyabinsk Oblast & 0.928 & - & + & + & - & + & + & - & + & + \\
\hline Stavropol Krai & 0.925 & - & + & + & - & + & + & - & + & + \\
\hline Orel Oblast & 0.917 & - & + & + & - & + & + & - & + & + \\
\hline Kostroma Oblast & 0.912 & - & + & + & - & + & + & - & + & + \\
\hline Murmansk Oblast & 0.908 & - & + & + & - & + & + & - & + & + \\
\hline Udmurt Republic & 0.908 & - & + & + & - & + & + & - & + & + \\
\hline Primorsky Krai & 0.905 & - & + & + & - & + & + & - & + & + \\
\hline Smolensk Oblast & 0.895 & + & + & + & + & + & + & + & + & + \\
\hline Republic of Karelia & 0.895 & + & + & + & + & + & + & + & + & + \\
\hline Kursk Oblast & 0.894 & + & + & + & + & + & + & + & + & + \\
\hline Altai Republic & 0.888 & + & + & + & + & + & + & + & + & + \\
\hline Ulyanovsk Oblast & 0.887 & + & + & + & + & + & + & + & + & + \\
\hline Saratov Oblast & 0.886 & + & + & + & + & + & + & + & + & + \\
\hline Altai Krai & 0.882 & + & + & + & + & + & + & + & + & + \\
\hline Perm Krai & 0.879 & + & + & + & + & + & + & + & + & + \\
\hline Ryazan Oblast & 0.877 & + & + & + & + & + & + & + & + & + \\
\hline Novgorod Oblast & 0.873 & + & + & + & + & + & + & + & + & + \\
\hline Chuvash Republic & 0.867 & + & + & + & + & + & + & + & + & + \\
\hline Tomsk Oblast & 0.857 & + & + & + & + & + & + & + & + & + \\
\hline Kirov Oblast & 0.847 & + & + & + & + & + & + & + & + & + \\
\hline Irkutsk Oblast & 0.835 & + & + & + & + & + & + & + & + & + \\
\hline Omsk Oblast & 0.834 & + & + & + & + & + & + & + & + & + \\
\hline Amur Oblast & 0.812 & + & + & + & + & + & + & - & - & - \\
\hline Kemerovo Oblast & 0.801 & + & + & + & + & + & + & - & - & - \\
\hline Pskov Oblast & 0.8 & + & + & + & + & + & + & - & - & - \\
\hline Mari El Republic & 0.794 & + & + & + & + & + & + & - & - & - \\
\hline Lipetsk Oblast & 0.79 & + & + & + & + & + & + & - & - & - \\
\hline Penza Oblast & 0.782 & + & + & + & + & + & + & - & - & - \\
\hline Republic of Buryatia & 0.775 & + & + & + & + & + & + & - & - & - \\
\hline Krasnoyarsk Krai & 0.774 & + & + & + & - & - & - & - & - & - \\
\hline Sakha (Yakutia) Republic & 0.762 & + & + & + & - & - & - & - & - & - \\
\hline
\end{tabular}

Please cite this article as: Krinichanskii K.V., Fat'kin A.V. Complex Issues of Regional Growth Dependence on the Level of Financial Sector 
K.V. Krinichanskii et al./ Digest Finance, 2017, volume 22, issue 3, pages 243-257

\begin{tabular}{llllllll}
\hline Leningrad Oblast & 0.762 & + & + & + & - & - & - \\
\hline Volgograd Oblast & 0.758 & + & + & + & - & - & - \\
\hline Arkhangelsk Oblast & 0.756 & + & + & + & - & - & - \\
\hline Tver Oblast & 0.745 & + & + & + & - & - & - \\
\hline Orenburg Oblast & 0.741 & + & + & + & - & - & - \\
\hline Tambov Oblast & 0.74 & + & + & + & - & - & - \\
\hline
\end{tabular}

Note. Criteria that determine the threshold values:

20-60 percentile group: $0.739<C B S D I<0.899 ; 20-70$ percentile group: $0.739<C B S D I<0.942 ; 20$-80 percentile group: $0.739<C B S D I<0.986$; 30-60 percentile group: $0.774<C B S D I<0.899 ; 30-70$ percentile group: $0.774<C B S D I<0.942 ; 30-80$ percentile group: $0.774<C B S D I<0.986$; 40-60 percentile group: $0.825<C B S D I<0.899 ; 40-70$ percentile group: $0.825<C B S D I<0.942 ; 40-80$ percentile group: $0.825<C B S D I<0.986$.

The region included in the group is marked with "+", the not included one is marked with "-".

Source:Authoring

Please cite this article as: Krinichanskii K.V., Fat'kin A.V. Complex Issues of Regional Growth Dependence on the Level of Financial Sector Development. Digest Finance, 2017, vol. 22, iss. 3, pp. 243-257. https://doi.org/10.24891/df.22.3.243 


\section{Table 3}

Groups of regions with higher financial development, by composite index of banking services density in the region, averaged for 2002-2014

\begin{tabular}{|c|c|c|c|c|}
\hline \multirow{2}{*}{ Region } & \multirow{2}{*}{$\begin{array}{l}\text { Financial Development } \\
\text { Indicator Value }\end{array}$} & \multicolumn{3}{|c|}{$\begin{array}{l}\text { Upper and lower percentile ranks, and the criteria that determine } \\
\text { the threshold values }\end{array}$} \\
\hline & & $\begin{array}{l}20 / 60,30 / 60,40 / 60 \\
0.899<C B S D I\end{array}$ & $\begin{array}{l}\text { 20/70,30/70, 40/70; } \\
0.942<\text { C CBSDI }\end{array}$ & $\begin{array}{l}20 / 80,30 / 80,40 / 80 \\
0.986<\text { C CBSDI }\end{array}$ \\
\hline Moscow & 1.742 & + & + & + \\
\hline St. Petersburg & 1.519 & + & + & + \\
\hline Kaliningrad Oblast & 1.284 & + & + & + \\
\hline Magadan Oblast & 1.256 & + & + & + \\
\hline Yaroslavl Oblast & 1.109 & + & + & + \\
\hline Sverdlovsk Oblast & 1.073 & + & + & + \\
\hline Kamchatka Krai & 1.06 & + & + & + \\
\hline Nizhny Novgorod Oblast & 1.034 & + & + & + \\
\hline Samara Oblast & 1.026 & + & + & + \\
\hline Vologda Oblast & 1.019 & + & + & + \\
\hline Rostov Oblast & 1.018 & + & + & + \\
\hline Krasnodar Krai & 1.008 & + & + & + \\
\hline Belgorod Oblast & 1.003 & + & + & + \\
\hline Novosibirsk Oblast & 1.002 & + & + & + \\
\hline Vladimir Oblast & 0.986 & + & + & + \\
\hline Moscow Oblast & 0.985 & + & + & - \\
\hline Voronezh Oblast & 0.977 & + & + & - \\
\hline Kaluga Oblast & 0.975 & + & + & - \\
\hline Republic of Tatarstan & 0.965 & + & + & - \\
\hline Tula Oblast & 0.959 & + & + & - \\
\hline Republic of Mordovia & 0.957 & + & + & - \\
\hline Khabarovsk Krai & 0.947 & + & + & - \\
\hline Ivanovo Oblast & 0.945 & + & + & - \\
\hline Chelyabinsk Oblast & 0.928 & + & - & - \\
\hline Stavropol Krai & 0.925 & + & - & - \\
\hline Orel Oblast & 0.917 & + & - & - \\
\hline Kostroma Oblast & 0.912 & + & - & - \\
\hline Murmansk Oblast & 0.908 & + & - & - \\
\hline Udmurt Republic & 0.908 & + & - & - \\
\hline Primorsky Krai & 0.905 & + & - & - \\
\hline
\end{tabular}

Note. The region included in the group is marked with "+", the not included one is marked with "-".

Source: Authoring

Please cite this article as: Krinichanskii K.V., Fat'kin A.V. Complex Issues of Regional Growth Dependence on the Level of Financial Sector 


\section{Table 4}

Classification options and assessment values of the tested variable Loans to Gross Regional Product

\begin{tabular}{|c|c|c|c|c|}
\hline Study subject & $\begin{array}{l}\text { Regions' financial } \\
\text { development level }\end{array}$ & $\begin{array}{l}\text { 60th percentile upper } \\
\text { limit } \\
\text { CBSDI>0.899 }\end{array}$ & $\begin{array}{l}\text { 70th percentile upper } \\
\text { limit } \\
\text { CBSDI>0.942 }\end{array}$ & $\begin{array}{l}\text { 80th percentile upper } \\
\text { limit } \\
C B S D I>0.986\end{array}$ \\
\hline \multirow[t]{3}{*}{$\begin{array}{l}\text { 20th percentile lower limit } \\
(C B S D I<0.739)\end{array}$} & Higher & $\begin{array}{l}0.289^{* * *} \\
(3.04)\end{array}$ & $\begin{array}{l}0.259^{* * *} \\
(2.64)\end{array}$ & $\begin{array}{l}0.253^{* *} \\
(2.48)\end{array}$ \\
\hline & Moderate & $\begin{array}{l}0.294^{* *} \\
(2.47)\end{array}$ & $\begin{array}{l}0.31^{* *} \\
(2.53)\end{array}$ & $\begin{array}{l}0.306^{* *} \\
(2.61)\end{array}$ \\
\hline & Lower & $\begin{array}{l}0.273^{* *} \\
(2.52)\end{array}$ & $\begin{array}{l}0.276^{* *} \\
(2.46)\end{array}$ & $\begin{array}{l}0.275^{* *} \\
(2.48)\end{array}$ \\
\hline \multirow[t]{3}{*}{$\begin{array}{l}\text { 30th percentile lower limit } \\
(C B S D I<0.774)\end{array}$} & Higher & $\begin{array}{l}0.284^{* * *} \\
(3.08)\end{array}$ & $\begin{array}{l}0.256^{* * *} \\
(2.66)\end{array}$ & $\begin{array}{l}0.25^{* *} \\
(2.49)\end{array}$ \\
\hline & Moderate & $\begin{array}{l}0.285^{* *} \\
(2.51)\end{array}$ & $\begin{array}{l}0.302^{* *} \\
(2.57)\end{array}$ & $\begin{array}{l}0.299^{* * *} \\
(2.65)\end{array}$ \\
\hline & Lower & $\begin{array}{l}0.286^{* *} \\
(2.47)\end{array}$ & $\begin{array}{l}0.288^{* *} \\
(2.4)\end{array}$ & $\begin{array}{l}0.288^{* *} \\
(2.41)\end{array}$ \\
\hline \multirow[t]{3}{*}{$\begin{array}{l}\text { 40th percentile lower limit } \\
(C B S D /<0.825)\end{array}$} & Higher & $\begin{array}{l}0.285^{* * *} \\
(3.15)\end{array}$ & $\begin{array}{l}0.252^{* * *} \\
(2.64)\end{array}$ & $\begin{array}{l}0.246^{* *} \\
(2.45)\end{array}$ \\
\hline & Moderate & $\begin{array}{l}0.265^{* *} \\
(2.37)\end{array}$ & $\begin{array}{l}0.287^{* *} \\
(2.47)\end{array}$ & $\begin{array}{l}0.285^{* *} \\
(2.55)\end{array}$ \\
\hline & Lower & $\begin{array}{l}0.311^{* * *} \\
(2.77)\end{array}$ & $\begin{array}{l}0.31^{* *} \\
(2.62)\end{array}$ & $\begin{array}{l}0.31^{* * *} \\
(2.63)\end{array}$ \\
\hline
\end{tabular}

Note. ${ }^{*} p<0.1,{ }^{* *} p<0.05,{ }^{* * *} p<0.01$; The values of $t$-statistics are indicated in parentheses.

Source: Authoring 


\section{Table 5}

Classification options and assessment values of the tested variable Deposits to Gross Regional Product

\begin{tabular}{|c|c|c|c|c|}
\hline Study subject & $\begin{array}{l}\text { Regions' financial } \\
\text { development level }\end{array}$ & $\begin{array}{l}\text { 60th percentile upper } \\
\text { limit } \\
C B S D I>0.899\end{array}$ & $\begin{array}{l}\text { 70th percentile upper } \\
\text { limit } \\
C B S D I>0.942\end{array}$ & $\begin{array}{l}\text { 80th percentile upper } \\
\text { limit } \\
C B S D I>0.986\end{array}$ \\
\hline \multirow[t]{3}{*}{$\begin{array}{l}\text { 20th percentile lower limit } \\
(C B S D I<0.739)\end{array}$} & Higher & $\begin{array}{l}0.711^{* * *} \\
(3.92)\end{array}$ & $\begin{array}{l}0.673^{* * *} \\
(3.89)\end{array}$ & $\begin{array}{l}0.646^{* * *} \\
(3.74)\end{array}$ \\
\hline & Moderate & $\begin{array}{l}0.961^{* * *} \\
(5.15)\end{array}$ & $\begin{array}{l}0.893^{* * *} \\
(5.27)\end{array}$ & $\begin{array}{l}0.852^{* * *} \\
(5.26)\end{array}$ \\
\hline & Lower & $\begin{array}{l}1.185^{* * *} \\
(5.38)\end{array}$ & $\begin{array}{l}1.138^{* * *} \\
(5.47)\end{array}$ & $\begin{array}{l}1.106^{* * *} \\
(5.51)\end{array}$ \\
\hline \multirow[t]{3}{*}{$\begin{array}{l}\text { 30th percentile lower limit } \\
(C B S D I<0.774)\end{array}$} & Higher & $\begin{array}{l}0.707^{* * *} \\
(3.88)\end{array}$ & $\begin{array}{l}0.671^{* * *} \\
(3.88)\end{array}$ & $\begin{array}{l}0.645^{* * *} \\
(3.76)\end{array}$ \\
\hline & Moderate & $\begin{array}{l}0.946^{* * *} \\
(5.09)\end{array}$ & $\begin{array}{l}0.884^{* * *} \\
(5.24)\end{array}$ & $\begin{array}{l}0.845^{* * *} \\
(5.25)\end{array}$ \\
\hline & Lower & $\begin{array}{l}1.149^{* * *} \\
(5.52)\end{array}$ & $\begin{array}{l}1.119^{* * *} \\
(5.71)\end{array}$ & $\begin{array}{l}1.095^{* * *} \\
(5.84)\end{array}$ \\
\hline \multirow[t]{3}{*}{$\begin{array}{l}\text { 40th percentile lower limit } \\
(C B S D I<0.825)\end{array}$} & Higher & $\begin{array}{l}0.706^{* * *} \\
(3.79)\end{array}$ & $\begin{array}{l}0.674^{* * *} \\
(3.82)\end{array}$ & $\begin{array}{l}0.649^{* * *} \\
(3.73)\end{array}$ \\
\hline & Moderate & $\begin{array}{l}0.923^{* * *} \\
(4.9)\end{array}$ & $\begin{array}{l}0.871^{* * *} \\
(5.13)\end{array}$ & $\begin{array}{l}0.839^{* * *} \\
(5.22)\end{array}$ \\
\hline & Lower & $\begin{array}{l}1.086^{* * *} \\
(5.35)\end{array}$ & $\begin{array}{l}1.085^{* * *} \\
(5.71)\end{array}$ & $\begin{array}{l}1.079^{* * *} \\
(5.96)\end{array}$ \\
\hline
\end{tabular}

Note. ${ }^{*} p<0.1,{ }^{* *} p<0.05,{ }^{* * *} p<0.01$; The values of $t$-statistics are indicated in parentheses.

Source: Authoring 
Table 6

Classification options and assessment values of the tested variable Number of Internal Structural Units per 10,000 People (A Natural Logarithm)

\begin{tabular}{|c|c|c|c|c|}
\hline Study subject & $\begin{array}{l}\text { Regions' financial } \\
\text { development level }\end{array}$ & $\begin{array}{l}\text { 60th percentile upper } \\
\text { limit } \\
\text { CBSDI>0.899 }\end{array}$ & $\begin{array}{l}\text { 70th percentile upper } \\
\text { limit } \\
\text { CBSDI >0.942 }\end{array}$ & $\begin{array}{l}\text { 80th percentile upper } \\
\text { limit } \\
C B S D I>0.986\end{array}$ \\
\hline \multirow[t]{3}{*}{$\begin{array}{l}\text { 20th percentile lower limit } \\
(C B S D I<0.739)\end{array}$} & Higher & $\begin{array}{l}0.094^{* *} \\
(2.23)\end{array}$ & $\begin{array}{l}0.086^{* *} \\
(2.18)\end{array}$ & $\begin{array}{l}0.086^{* *} \\
(2.24)\end{array}$ \\
\hline & Moderate & $\begin{array}{l}0.126^{* * *} \\
(2.93)\end{array}$ & $\begin{array}{l}0.121^{* * *} \\
(2.78)\end{array}$ & $\begin{array}{l}0.116^{* * *} \\
(2.65)\end{array}$ \\
\hline & Lower & $\begin{array}{l}0.133^{* *} \\
(2.62)\end{array}$ & $\begin{array}{l}0.128^{* *} \\
(2.53)\end{array}$ & $\begin{array}{l}0.124^{* *} \\
(2.46)\end{array}$ \\
\hline \multirow[t]{3}{*}{$\begin{array}{l}\text { 30th percentile lower limit } \\
(C B S D I<0.774)\end{array}$} & Higher & $\begin{array}{l}0.094^{* *} \\
(2.28) \\
\end{array}$ & $\begin{array}{l}0.086^{* *} \\
(2.22)\end{array}$ & $\begin{array}{l}0.087^{* *} \\
(2.28)\end{array}$ \\
\hline & Moderate & $\begin{array}{l}0.13^{* * *} \\
(3.12)\end{array}$ & $\begin{array}{l}0.124^{* * *} \\
(2.9)\end{array}$ & $\begin{array}{l}0.118^{* * *} \\
(2.74)\end{array}$ \\
\hline & Lower & $\begin{array}{l}0.122^{* *} \\
(2.49) \\
\end{array}$ & $\begin{array}{l}0.117^{* *} \\
(2.38)\end{array}$ & $\begin{array}{l}0.114^{* *} \\
(2.3)\end{array}$ \\
\hline \multirow[t]{3}{*}{$\begin{array}{l}\text { 40th percentile lower limit } \\
(C B S D I<0.825)\end{array}$} & Higher & $\begin{array}{l}0.095^{* *} \\
(2.28)\end{array}$ & $\begin{array}{l}0.087^{* *} \\
(2.19)\end{array}$ & $\begin{array}{l}0.087^{* *} \\
(2.28)\end{array}$ \\
\hline & Moderate & $\begin{array}{l}0.133^{* * *} \\
(3.11)\end{array}$ & $\begin{array}{l}0.124^{* * *} \\
(2.83)\end{array}$ & $\begin{array}{l}0.117^{* * *} \\
(2.65)\end{array}$ \\
\hline & Lower & $\begin{array}{l}0.124^{* * *} \\
(2.72)\end{array}$ & $\begin{array}{l}0.12^{* * *} \\
(2.59)\end{array}$ & $\begin{array}{l}0.117^{* *} \\
(2.51)\end{array}$ \\
\hline
\end{tabular}

Note. ${ }^{*} p<0.1,{ }^{* *} p<0.05,{ }^{* * *} p<0.01$; The values of $t$-statistics are indicated in parentheses.

Source:Authoring

Figure 1

Financial development indicator thresholds

\begin{tabular}{|c|c|c|c|}
\hline \multicolumn{2}{|c|}{$\begin{array}{l}\text { Thresholds that determine the transition to a lowerlevel } \\
\text { of financial development }\end{array}$} & \multicolumn{2}{|c|}{$\begin{array}{l}\text { Thresholds that determine the transition to a higher level } \\
\text { of financial development }\end{array}$} \\
\hline 20th percentile & $C B S D I<0.739$ & 60th percentile & $0.899<$ CBSDI \\
\hline $\begin{array}{l}\text { Number of regions that meet } \\
\text { the criteria }\end{array}$ & 15 & $\begin{array}{l}\text { Number of regions that meet } \\
\text { the criteria }\end{array}$ & 30 \\
\hline 30th percentile & $C B S D I<0.774$ & 70th percentile & $0.942<$ CBSDI \\
\hline $\begin{array}{l}\text { Number of regions that meet } \\
\text { the criteria }\end{array}$ & 23 & $\begin{array}{l}\text { Number of regions that meet } \\
\text { the criteria }\end{array}$ & 23 \\
\hline 40th percentile & $C B S D I<0.825$ & 80th percentile & $0.986<C B S D I$ \\
\hline $\begin{array}{l}\text { Number of regions that meet } \\
\text { the criteria }\end{array}$ & 30 & $\begin{array}{l}\text { Number of regions that meet } \\
\text { the criteria }\end{array}$ & 15 \\
\hline
\end{tabular}

Source:Authoring

Please cite this article as: Krinichanskii K.V., Fat'kin A.V. Complex Issues of Regional Growth Dependence on the Level of Financial Sector Development. Digest Finance, 2017, vol. 22, iss. 3, pp. 243-257. 


\section{References}

1. Acemoglu D., Dell M. Productivity Differences Between and Within Countries. American Economic Journal: Macroeconomics, 2010, vol. 2, no. 1, pp. 169-188. doi: 10.3386/w15155

2. D'Costa S., Garcilazo E., Martins J.O. The Impact of Structural and Macroeconomic Factors on Regional Growth. OECD Regional Development Working Papers, 2013, no. 2013/11. OECD Publishing, Paris. URL: https://dx.doi.org/10.1787/5k451 mplq9/w-en

3. Krugman P., Venables A.J. Integration, Specialization, and the Adjustment. European Economic Review, 1996, vol. 40, iss. 3-5, pp. 959-968. doi: 10.3386/w4559

4. Schumpeter J.A. Teoriya ekonomicheskogo razvitiya. Kapitalizm, sotsializm i demokratiya [Capitalism, Socialism and Democracy]. Moscow, Eksmo Publ., 2007, 864 p.

5. Hicks J. A Theory of Economic History. Oxford, Clarendon Press, 1969, 181 p.

6. Goldsmith R.W. Financial Structure and Development. New Haven, Yale University Press, 1969,561 p.

7. McKinnon R.I. Money and Capital in Economic Development. Washington DC, Brookings Institution, 1973,184 p.

8. King R.G., Levine R. Financial Intermediation and Economic Development. In: Colin M., Xavier V. (Eds) Financial Intermediation in the Construction of Europe. London, Centre of Economic Policy Research, 1993, pp. 156-189.

9. King R.G., Levine R. Finance and Growth: Schumpeter Might Be Right. Quarterly Journal of Economics, 1993, vol. 108, no. 3, pp. 717-737.

10. King R.G., Levine R. Finance, Entrepreneurship, and Growth: Theory and Evidence. Journal of Monetary Economics, 1993, vol. 32, iss. 3, pp. 513-542.

11. Beck T., Levine R., Loayza N. Finance and the Sources of Growth. Journal of Financial Economics, 2000, vol. 58, iss. 1,2 , pp. 261-300. doi: 10.1016/S0304-405X(00)00072-6

12. Guiso L., Sapienza P., Zingales L. Does Local Financial Development Matter? The Quarterly Journal of Economics, 2004, vol. 119, iss. 3, pp. 929-969. doi: 10.1162/0033553041502162

13. Cheng X., Degryse H. The Impact of Bank and Non-Bank Financial Institutions on Local Economic Growth in China. Journal of Financial Services Research, 2010, vol. 37, no. 2, pp. 179-199. doi: 10.1007/s10693-009-0077-4

14. Kendall J. Local Financial Development and Growth. Journal of Banking and Finance, 2012, vol. 36, iss. 5, pp. 1548-1562. doi: 10.1016/j.jbankfin.2012.01.001

15. Zhang J., Wang L., Wang S. Financial Development and Economic Growth: Evidence from China. Journal of Comparative Economics, 2012, vol. 40, iss. 3, pp. 393-412. doi:10.1016/j.jce.2012.01.001

16. Demetriades P., Hussien K. Does Financial Development Cause Economic Growth? Time Series Evidence from 16 Countries. Journal of Development Economics, 1996, vol. 51, iss. 2, pp. 387-411. doi: 10.1016/S0304-3878(96)00421-X

17. Rioja F., Valev N. Finance and the Sources of Growth at Various Stages of Economic Development. Economic Inquiry, 2004, vol. 42, iss. 1, pp. 127-140. doi: 10.1093/ei/cbh049 
18. Odedokun M.O. Alternative Econometric Approaches for Analyzing the Role of the Financial Sector in Economic Growth: Time Series Evidence from LDC's. Journal of Development Economics, 1996, vol. 50, iss. 1, pp. 119-146. doi: 10.1016/0304-3878(96)00006-5

19. Levine R., Loayza N., Beck T. Financial Intermediation and Growth: Causality and Causes. Journal of Monetary Economics, 2000, vol. 46, iss. 1, pp. 31-77. doi: 10.1016/S0304-3932(00)00017-9

20. De Gregorio J., Guidotti P. Financial Development and Economic Growth. World Development, 1995, vol. 23, iss. 3, pp. 433-448. doi: 10.1016/0305-750X(94)00132-I

21. Rioja F., Valev N. Does One Size Fit All?: A Reexamination of the Finance and Growth Relationship. Journal of Development Economics, 2004, vol. 74, iss. 2, pp. 429-447. doi: 10.1016/j.jdeveco.2003.06.006

22. Krinichanskii K.V. [Financial Systems and Economic Development in the Russian Regions: A Comparative Analysis]. Voprosy Ekonomiki, 2015, no. 10, pp. 94-108. (In Russ.)

23. Berezinskaya O. [Lending to the non-financial sector: Opportunities and limitations]. Voprosy Ekonomiki, 2016, no. 3, pp. 63-74. (In Russ.)

\section{Conflict-of-interest notification}

We, the authors of this article, bindingly and explicitly declare of the partial and total lack of actual or potential conflict of interest with any other third party whatsoever, which may arise as a result of the publication of this article. This statement relates to the study, data collection and interpretation, writing and preparation of the article, and the decision to submit the manuscript for publication. 